$\begin{array}{r}\begin{array}{l}\text { Interdisciplinary Contexts of Special Pedagogy } \\ \text { NUMER 25/2019 }\end{array} \\ \text { OLGA CHRZANOWSKA } \\ \text { Lodz Univeristy of Technology, Poland } \\ \hline\end{array}$

\title{
Contemporary architect's self-education on the issues concerning architecture history. Selected problems
}

\begin{abstract}
Olga Chrzanowska, Contemporary architect's self-education on the issues concerning architecture history. Selected problems. Interdisciplinary Contexts of Special Pedagogy, no. 25, Poznań 2019. Pp. 403-417. Adam Mickiewicz University Press. ISSN 2300-391X. DOI: https:/ / doi.org/10.14746/ikps.2019.25.17

The aim of this text is to describe the risks faced by contemporary architects when undertaking to learn, either directly or indirectly, about architecture in the era of the Internet and mass consumption of culture. The role of architect's self-education on the issues concerning architecture history and aesthetic empathy theory in the context of everyday architectural landscapes. As an example, the historical foundations for the thinking on modernity in designs of the three architects: Peter Zumthor, Christian de Portzamparc and David Chipperfield
\end{abstract}

KEY WORDS: architecture, history, education

Modern architecture can be understood as a free creative activity based on sublimation of sensations and dreams. As Arvo Pärt, a contemporary Estonian composer and musician, put it: "In art everything is possible, but everything is not necessary". ${ }^{1}$ Architec-

${ }^{1}$ The quote is sourced from the interview carried out by Icelandic singer Björk with Arvo Pärt in a TV documentary series Modern Minimalists produced by BBC in 1997, https://youtube.com/watch?v=9hTLf8Nz160 [accessed on 27.02.2016]. 
ture is an extension of man - the past and the future of his life. A building, an architectural design, is the transfer of our qualities and wishes beyond our own body into the body of architecture, into the context of orderly, desirable space.

Recognizing creative freedom as an enormous professional opportunity is a difficult task. In most cases, as Polish painter Jerzy Nowosielski approaches it: "The mere fact of emergence of a sense of freedom in mentally, artistically, intellectually and emotionally weaker individuals simply provokes panic. (...) (...) They (...) want to be in this circle of freedom but have no enough power to do so. That is why they perform a whole series of ostensible actions, which are simply the margin of the mystification accompanying practically all the great phenomena in the field of culture and human development". ${ }^{2}$ Paraphrasing the Nowosielski's words: "The essence of a painting (...) is sublimation of our sensations and dreams" 3 , one may say that every creative activity: whether architectural, literary, scientific or musical is also sublimation of our sensations and dreams. So to get the most out of creative work, both of these components must be brought to resonance. To have the courage to dream, and to have the opportunity to fully experience. These two conditions are very difficult to fulfil today. We need to consciously and fully explore ourselves and the culture we live in to turn everything we know and feel into everything we want to express.

The difficulties in learning about architecture today appear when we try to get acquainted with architecture indirectly. "Some perverse people like a poem more than the art of writing poems, because they have nurtured more their ears than their minds," ${ }^{4}$ as

${ }^{2}$ Quote from the interview given by Jerzy Nowosielski to Jerzy Beres in the Krzysztofory Palace in 1984, as cited in: Krystyna Czerni, Jerzy Nowosielski Sztuka po końcu świata Rozmowy, 2012, p. 116.

${ }^{3}$ Quote from the interview given by Jerzy Nowosielski to the editorial board of the journal Projekt, 1973, as cited in: Krystyna Czerni, Jerzy Nowosielski Sztuka po końcu świata Rozmowy, 2012, p. 86.

${ }^{4}$ Quote from Aurelius Augustinus, De vera religione, ca. AD 386, as cited in: Władysław Tatarkiewicz, Historia Estetyki II, 1960, p. 79. 
St. Augustine, a philosopher of late Antiquity and early Middle Ages, claimed. Without language proficiency, we will not create a poem. Without knowledge of architectural language, we will not create architecture. To know each object, there are two essential possibilities of access: direct or indirect. Each of these forms has its advantages and disadvantages.

When experiencing reality directly we may only rely, at the moment, on ourselves, on our educational background, knowledge and sensitivity. Walking near the excellent Parisian cathedral, I try to comprehend its overwhelming complexity. While standing in a colonnade near the Italian square, at the moment of rest, I am sketching a view I see. I pass by a nineteenth century palace on my way to work. Every time I undertake a personal experience of architecture, I have access to full information, complete information, encoded in its physical form. Depending on my attitude, I can read from every work the values regarding the form and function, shapes, proportions and their purpose in different architectural solutions. I first read the information encoded in the buildings, then re-encode it for myself, in the form of notes and sketches. This is usually labour-intensive, requiring a large concentration and the skill of valuing. This teaches basic analytic and synthetic skills.

Based on a work of art we create (in part or in whole) our successive works of art. By painting the Rouen cathedral at different times of the day like Monet did 5 , I give to myself and the others the knowledge both of the cathedral and my experience of it. I draw a projection and dependencies in this nineteenth-century palace I visit in order to use this knowledge later for designing a house, so as to ensure its future inhabitants a sense of comfort and luxury without having to invest in "golden door knobs". A direct contact, even one that assumes the experience of architecture, or any other work of culture, may not be sufficient. The fullness of cognition can

5 This refers to the series of Claude Monet's paintings of the 1890s depicting the façade of the Rouen cathedral at various moments of the day and in different weather conditions. 
only be possible in the circumstances of doing further work, not only reading, but also interpreting, describing, recording the conclusions, self-study. The mere reading of someone else's poems will not make us better writers. The way in which we experience interpret and remember the reality is the first step in our creative workshop.

For indirect experience and current almost unrestricted access to information there are also certain risks. "Without being copied, the original would be forgotten. But paradoxically, the copy is a different painting; it caries another meaning from original. This is why the copy could define a story different from art history"6 wrote the contemporary philosopher Walter Benjamin. The 21st century we now live in may seem perfect in cognitive terms. The Internet, a growing number of companies publishing books, magazines, albums and the wide and unrestricted access to them, were designed to facilitate the acquisition of knowledge, accelerate education, maximise the collection of knowledge sources. This seemingly enormous potential, in the context of the need for deep and full knowledge, necessary in the process of creating our works, includes two essential pitfalls defined long ago by two modern thinkers.

The first pitfall is the consumption and absorption of shallow information, described below in the context of Zygmunt Bauman's reflections on culture in liquid modernity. ${ }^{7}$ The huge problem of contemporary generations, partly submerged in digital reality from the very beginning, is that their cognition of culture is not based on real contact with it and full experience of it. This would not be such a significant threat if it were not for the fact that culture and all information about it are nowadays particularly strongly affected by the laws of the market, which has two significant consequences observed by Zygmunt Bauman.

First, there is a typical market game since culture is defined by the market as a product and the recipient as a consumer. The prod-

\footnotetext{
${ }^{6}$ Quote from Walter Benjamin's, Recent Writings, 2013, p. 112.

7 Based on Zygmunt Bauman's, Kultura w ptynnej nowoczesności, 2011 (Culture in a Liquid Modern World).
} 
uct (culture) struggles to "attract unbearably volatile and dispersed attention from potential customers". ${ }^{8}$ Thus, the processed information provided to us becomes flattened or exaggerated and sometimes shortens its spectrum of meanings to be faster "consumed". Even viewing a hundred pictures of a cathedral may turn out to be poorer than its physical experience, and even a three-dimensional model on a computer screen does not convey the sense of scale and emotion accompanying personal, physical exploration of the building.

Bauman claims: "The culture of liquid modernity has no 'people' to enlighten and ennoble; however, it has customers to seduce. ${ }^{9}$ The lack of the mission of "enlightening and ennobling the people" is replaced by a plan to provide, as soon as possible and as much possible information, often superficial. In this way, what was supposed to free us and drive our development turns out to be a pitfall. Functioning in such a market-relativised reality can be a threat to contemporary architects.

The second pitfall is the growing role of copying and the disappearance of responsibility in today's bureaucratic world, described below on the basis of Walter Benjamin's thoughts. In the context of the quote cited at the beginning of the chapter, there is no physical possibility to base one's entire knowledge solely on the personal experience of the greatest works of culture. All the more so because every transformation is a separate work, be it an image of a painting, a picture of architecture, or a review of a spectacle. Since we have to rely in part on accounts told by others, we have to ask ourselves the question of whom and why we will choose as our guide.

When receiving someone else's message, we depend on his or her ability to analyse and synthesize, we read "someone else's notes". The only information available to us concerns things that this person considered worth noting, preserving or explaining. Encoded in the manner in which this person could encode it. The field

${ }^{8}$ Quote from Zygmunt Bauman's, Kultura w ptynnej nowoczesności, 2011.

${ }^{9}$ Quote from Zygmunt Bauman's, Kultura w ptynnej nowoczesności 2011, p. 30. 
for our interpretation remains only within the scope of the material provided to us. Therefore, in the absence of responsibility of the author, or his reviewers, for the process of information processing, the most important idea of the matter may be distorted or completely forgotten. Every building will eventually dilapidate, every image will became brittle, the whole material essence of reality will eventually be destroyed, and only its ideas will be passed on in a more or less skilful way.

Creative modernity can also be a constant rediscovery, it can be convinced of the power of old architecture and the power of distance in time. Jan Białostocki, a humanist and art historian, wrote: Although the modern house is certainly more technically perfect and comfortable than old buildings, although it may also be beautiful, it is difficult to say whether it is more beautiful than pieces of old architecture. For in the field of aesthetic value there is no such progress as in technology or science $^{10}$. If the fullness of personal cognition is so essential for creation, the question remains: where to head to? Contemporary architecture may turn out to be very deceptive in this case, as it will be easy for us to fall into the trap of copying, without a deeper understanding. Without specialist knowledge and intuition, we may not recognize the functions of certain formal effects in historical buildings and even fail to try processing them. In the case of contemporary architecture, which uses materials and technologies an aesthetics we are familiar with, we sometimes succumb to the illusion that its language and expression are equally understandable to us. We ask ourselves why architect Frank Gehry uses such liquid, bent forms in his designs, why they are bent in this way, what role does this play? Should we also bend the planes in our buildings to make them modern? Another very popular example in contemporary architecture is glass, with its captivating transparency, which in large areas is not a constructional challenge today. Will it give our projects the desired expression of courage and intransigence? The true essence of freedom in modern buildings can be overlooked

${ }^{10}$ Quote from Jan Białostocki, Sztuka cenniejsza niż złoto, 2006, p. 17. 
when we are attracted by their superficial charm. It is extremely dangerous to use expressions that seemingly mean modernity without being aware of their sense. An additional difficulty is the fact that there are not too many real pieces of modernity, that they are not yet so widely known and understood, and that their truly modern essence often remains a mystery to us.

The nature of old architecture established in our eyes, may not delight a less sensitive observer. However, it can be a good source in the context of the search for universal architectural values. Distance in time may make it easier to evaluate and draw conclusions. Furthermore, historical architecture rarely looks "brand-new": in most cases it has changed its function or owner several times, has been extended or some of its elements have been replaced This natural patina (often completely eliminated during renovations) shows us that architecture is transforming, giving us a lesson about transformations in time, which will happen to our works as well. On a well-made sculpture, even dirt and moisture are arranged in a manner that makes it better-looking.

On a daily basis, we speak our contemporary language with contemporary people and their works, we understand each other. In order to be able to interview an artist who died long ago (sometimes even centuries ago) and his work, a greater effort has to be made both on our and his part. As the English writer L.P. Hartley rightly pointed out: "The past is a foreign country; they do things differently there."11 Thus, at the level of message, the pieces of work of the past era must be more versatile in order to deliver some content to the next generations. We often carry out conversations with great artists and their works, which may take even a lifetime.

The aesthetic empathy theory also works well for everyday landscapes. We should explore and experience architecture not only on rare occasions. We are fascinated by the most time-honoured, most popular pieces of painting, sculpture, architecture, and often

${ }^{11}$ Quote from the novel by P. Hartley, Postaniec, 1992 (The Go-Between), as cited by Zygmunt Bauman, Między chwila a pięknem o sztuce w rozpędzonym świecie, 2010, p. 79. 
we do not realize that the same ideas can be met in our immediate surroundings. Historian and critic of literature Piotr Śliwiński, in the article "Poetry is a dead serious matter" writes: "This is because we quickly stop reading poems when we believe that they are supposed to be a repetition of what we already know. We stay with them when we assume that they are rather against what has emerged on surface, and for what is either hidden inside or obliterated". ${ }^{12}$ The same is the case with this local, everyday architecture, buildings in our neighbourhood. With the right focus, we will be able to notice in them the same ideas seen in the greatest, most perfect works, maybe in a slightly less voiced way. But they have a huge advantage, they are with us all the time. We learn them, we experience them in different circumstances, when we are satisfied, tired, in any weather conditions. Thus, the fullness of sensations and emotions opens before us. We discover our surroundings anew and infinitely when we realize how the way we perceive them changes depending on our age and the passage of time. Such impressions can remain impossible with occasional, single or severaltime contact even with the greatest work of culture. The landscape that accompanies us throughout our lives is for us a fullness we can feel with all our senses. When I assume that I will not learn anything new from a 19th-century palace passing it almost every day (because it is not the Louvre), I can lose a lot. The strength of fullness of cognition in a broader spatial context, the strength of the absorption of the reality surrounding us, can be of great importance for making both small decisions and those that shape us as architects.

The local heritage must not be rejected in favour of the global one, because this global heritage was once local. It is possible that in the so-called "mainstream" we do not find what represents our values and things most important to us. Hence, paying attention only to what is just currently being rewarded and widely promoted,

12 From the Piotra Śliwiński's article Poezja to sprawa gardłowa for "Gazeta Wyborcza” (in the „Duży Format” weekly magazine) of 04.02.16. 
may not lead us to the depths of our experiences and needs, so important in the creative process. Indeed, ,, at the bottom of every creativity, there must be a bit of stupidity"13, naivety, mismatch. A conservative attitude is often not a prevailing domain within culture. The journey into the depths of one's own thoughts and desires, the essence of oneself and one's surroundings, looked out for and dreamed of, is what develops us.

The historical foundations of modernity can also be found in the workshop of contemporary architects. The achievements of many contemporary architects prove the thesis that with a deep understanding of local, historical architecture thoroughly modern works can be created. These undoubtedly include: Peter Zumthor, Christian de Portzamparc and David Chipperfield. By their practice, they confirm that knowledge of universal architectural values and deep listening to the place and their own desires translates into architectural concepts. The descriptions of pieces of architecture presented below, one for each of these architects, are dated from 1979 to 2009 and show different dimensions of the foundations of modernity.

David Chipperfield and his modernity accompanying historical buildings, draws on the same sources as historical buildings, but with even more courage. The Neues Museum (to be more specific, the reconstruction of the Neues Museum in Berlin, Germany 1997-2009) in its current form is a combination of two designs seeking the foundation in past eras. The original nineteenth-century part of the building referring to the architecture of ancient Greece, Rome and Egypt was partially destroyed. The contemporary reconstruction from the turn of the 20th and 21st centuries combines modern elements with the remains of the previous building, giving the impression of a coherent whole. This provides the basis for the further relation: the same principle as in the nineteenth century, namely the concept of referring to classical styles, is applied to the added parts of the building.

13 As cited in Teresa Tyszkiewiczowa, Notatki 1940-1983, p. 116. 
When looking at the Neues Museum from afar, one feels peace and unity in its silhouette. The consistency in the construction of the synthetic architectural expression of the new and old parts is manifested at the most literal level in identical building materials: brick and plaster. Next, the common language of architecture talks about architectural orders through cornices, window frames, niches with reliefs. Finally, the overall picture composed of colours and shapes and their relationships suggest that the "sewn" and "patched" architectural work can still be harmonious. Modernity has no reason to come to the fore here, it has a common goal with the historical fabric. Therefore, the viewer first notices the whole thing, only then begins to look for subtle signs and differences between the two designs.

Slowly approaching the building, one can feel the suggestions of modernity. The contemporary part - the corner - begins to stand out through its special arrangement. The following are the most prominent: the post-modernist asceticism of the exterior shell, postdeconstructionist breaks in the lines of corner edges, location of niches with reliefs, which now reveal a subtle asymmetry in arrangement. Even without architectural education, it can be concluded that it cannot be the nineteenth century, that it has a modern form.

Having entered the main hall of the building, the visitors are shown a majestic staircase with a subtle detail. The semi-circular shape of the railing, the fins and their mutual relationship and the composition with the mass of the entire balustrade show the inspiration by historical styles. However, unlike the 19th-century thinking about architectural history, modern reconstruction does not literally copy the details and shapes of antiquity. The Neues Museum design is understood as lessons learned from classic styles and then the use of these ideas in a contemporary style.

Peter Zumthor and his modernity in unison with the landscape is seen in his work, the St. Benedict Chapel in Sumvig, Switzerland 1985-1988. The Peter Zumthor's architectural and literary works contain many threads regarding memory, personal feelings and 
resulting ideas. In his book „Thinking Architecture” the architect writes:

When I concentrate on a specific site or place for which I am going to design a building, when I try to plumb its depths, its form, its history, and its sensuous qualities, images of other places start to invade this process of precise observation: images of places I know and that once impressed me, images of ordinary or special places places that I carry with me as inner visions of specific moods and qualities; images of architectural situations, which emanate from the world of art, or films, theatre or literature. ${ }^{14}$

This description provided by the author gives the insight in his workshop of creative process. It shows us the inseparability of the perception of architecture with inquiring into the works of culture influencing the creation of new, further meanings in the mind of the creator.

The St. Benedict Chapel is in its fundamental dimension a site of worship and meditation: hiding, isolating the human from reality, a symbol of faith, and at the same time a fragment of the mountain landscape. Its rounded silhouette, uncluttered by anything but the modest entrance, grows into the countryside. So, like subsequent hills in the valley, also the curvature of the chapel leads the viewer's eyes further into the subsequent layers of the picturesque view. The regular layout of the building grows out of the slope resembling a bastion, to turn into windows allowing the daylight into the interior from above, and a delicate roof with a small cross.

The building does not sanctify per se the religious symbols and the most exquisite styles associated with the religious tradition. The reflection can be found here in the undisturbed peace of prayer and the deliberate writing of the human creation, which is the temple, into a formula respecting the surrounding landscape. It turns out, therefore, that its is not specific forms that carry a specific connotation. Eventually, the whole architecture comes down to the mutual

${ }^{14}$ Quote from Peter Zumthor, Myślenie architektura, 2010, p. 41. 
relationship between the same elements: the entrances, walls, windows, roof, and that their narration decides on the harmony with the site and role of the building in the environment. The common denominator for the Renaissance basilica in the centre of Rome and the lonely chapel above several houses in a Swiss mountain valley is the purposefulness of expression and legibility resulting from the prudent selection of forms and giving them specific meanings.

In Christian de Portzamparc's work, modernity appears in classical canons in residential buildings at rue des Hautes Formes, Paris, France 1979. In contemporary Paris, the buildings located at the street of "high forms"15 attract attention. Its spirit, however modern, seems to refer to the same principles as the nineteenthcentury Opéra Garnier, so well-known and admired Parisian monument. These buildings are mutually linked by traditional canons of scale $^{16}$, number ${ }^{17}$ and hierarchy ${ }^{18}$, although each time they are presented in a different spirit of a given era.

The canon of numbers determines the main division of the form into its constituent parts. Odd numbers are always more readable than even numbers, and it is simpler to read less divisions. The height and scale of the Christian de Portzamparc's eleven-storey residential building are initially difficult to estimate. However, if we look at the niches connecting the windows of each of subsequent two storeys, it turns out that reducing the elements from ten to five makes it intuitively easier to assess the height of the building. Similarly, in the Opéra Garnier, the complex cross-section with many rooms of various sizes and interior locations is reflected in the façade with a clear five-part layout. A well applied canon of numbers makes it easier to understand the structure.

${ }^{15}$ Les hautes formes means high forms in French.

16 Based on: Steven W. Semes, The future of the past, chapter two The Principles of Traditional Architecture, 2009, pp. 45-49.

17 Based on: Trystan Edwards, Architectural style 1926, as cited in: Steven W. Semes, The future of the past, chapter two The Principles of Traditional Architecture, 2009, pp. 58-59.

18 As above. 
The canon of hierarchy defines the character of the base, the main core and the top of the building. With appropriate accentuation of each of these parts, their role in the whole can be readable for us. Even the Le Corbusier's chapel in Ronchamp, which even uses such abstract forms, is classic in this respect. In the Parisian Hautes Formes, the ground floors of the building are broken down by wide pedestrian and vehicle passages, the central core is counted with the canon of numbers, while the end of the building is suggested by clear, empty windows with a view of the sky - a kind of crowns for these skyscrapers.

The canon of scale defines the need to design elements with the use of the appropriate form an function for distant, closer and detailed views.. Observing this residential complex from a distant perspective, the slender towers connected to each other above half of their height remind us of ponderous gates. Upon entering the inner courtyard, the buildings are lower and, like a broken vessel, let in light beams. The details of the windows, loggias and balconies in the form of modernist and post-modernist compositions decide on detailed elaboration of the perspectives closest to the viewer.

By fulfilling all these conditions of classical composition, the architecture of the rue des Hautes Formes fits into the context and structure of Paris. Despite its high altitude, high intensity of land development and completely modern forms, its expression is in many respects consistent with the central part of the city, which is so popular among visitors.

The process of creation is carried out in parallel in each phase: of observation, thought, workshop and finally in the work itself. By depriving ourselves of the full participation in any of them, besides that it translates to a worse end result, we get rid also of the opportunity to know ourselves more deeply. We are going out of work with what we came from. And the mission of being an architect, a critic of architecture or a designer seems to be greater than our fears - whether we can find deep inside in ourselves the right emotions and values and whether we can develop them. More often than we expect, the hints are closer than we think and they are 
about to be discovered. I will conclude with the statement of of Ebenezer Howard, the author of the concept of garden cities, who said that one never has to be too realist in humanitarian plans. All in all, there is too much difficulty and always only a weak percentage of aspirations can materialize. Therefore, these aspirations should reach as far as possible to have sufficient area to lose, because we cannot say about considerable profits. The percentage of losses depends only on the enthusiasm, energy and perseverance of idealists taking up the work. ${ }^{19}$

\section{Bibliography}

Bauman Z., Kultura w ptynnej nowoczesności, Wydawnictwo Agora, Warszawa 2011.

Bauman Z., Między chwila a pięknem o sztuce w rozpędzonym świecie, Wydawnictwo Officyna, Łódź 2010.

Benjamin W., Recent Writings, New Documents, Vancouver Canada, L.A. USA 2013.

Białostocki J., Sztuka cenniejsza niż złoto, Wydawnictwo Naukowe PWN, Warszawa 2006.

Czerni K., Jerzy Nowosielski Sztuka po końcu świata Rozmowy, Wydawnictwo Znak, Kraków 2012.

Ostrowski W., Urbanistyka wspótczesna, Wydawnictwo Arkady, Wrocław 1975.

Semes S., The future of the past, W.W. Norton and Company, New York, USA, London, England 2009.

Śliwiński P., Poezja to sprawa gardtowa, Gazeta Wyborcza dodatek Duży Format 04.02.16.

Tatarkiewicz W., Historia Estetyki tom II Estetyka Średniowieczna, Wydawnictwo Zakład Narodowy imienia Ossolińskich, Wrocław 1960.

Tyszkiewiczowa T., Notatki 1940-1983, Instytut Wydawniczy Książka i Prasa, Warszawa 2013.

Zumthor P., Myślenie architektura, Wydawnictwo Karakter, Kraków 2010.

Internet sources

Interview given by Arvo Pärt to Björk, Modern Minimalists, BBC documentaries 1997, at: https://youtube.com/watch?v=9hTLf8Nz160 [accessed on 27.02.2016]

${ }^{19}$ Quote from Gazeta Architekt sierpień 1912, as cited by Wacław Ostrowski, Urbanistyka wspótczesna, 1975, p. 32. 
List of illustrations

All the photographs are the property of the author.

1. A person drawing from life, Rome, Italy 2016

2. Sketchbooks and notepads, 2016

3. Bent glazing and walls from the 19th century in the Karol Poznański's palace at ul. Gdańska, view of the northern façade, Łódź, Poland 2016

4. Proportions of roof and walls in a simple 19th century house, Zgierz, Poland 2016

5. The Louvre, Paris, France 2016

6. the so-called Louvre of Łódź, the palace of Izrael Poznanski from the 19th century at ul. Ogrodowa, view from the garden, Łódź, Poland 2016

7. Erechtheion on the Acropolis, detail, Athens, Greece 2008

8. Modern corner of the Neues Museum, Berlin, Germany 2015

9. Details of the modern railing at the Neues Museum, Berlin, Germany 2015

10. St. Peter's Basilica in Rome, Italy 2012

11. Pastel drawing of the St. Benedict's Chapel in Sumvig (the author of the drawing will be revealed after decoding the study), 2012

12. Tower, a simple form of great universality, Sforza Castle from the 15th to the 16th centuries, view to the north from Piazza Castello, Milan, Italy 2014

13. Residential development at rue des HautesFormes, view from avenue Edison eastwards, Paris, France 2016

14. Cross-section of Opéra Garnier, view of a model (the model is part of the exhibition at Musee d'Orsay), Paris, France 2016 